\title{
PENGEMBANGAN MEDIA PEMBELAJARAN TATA SURYA BERBASIS VIRTUAL REALITY UNTUK SISWA KELAS 6 SEKOLAH DASAR DENGAN EVALUASI KEPUASAN PENGGUNA TERHADAP ELEMEN MULTIMEDIA
}

\author{
Yuli Purwati ${ }^{1}$, Selvi Sagita ${ }^{2}$, Fandy Setyo Utomo*3, Wiga Maulana Baihaqi ${ }^{4}$ \\ 1,2,3,4 STMIK AMIKOM Purwokerto \\ Email: 1yulipurwati@amikompurwokerto.ac.id, 2selvi_sagita@yahoo.co.id, \\ ${ }^{3}$ fandy_setyo_utomo@amikompurwokerto.ac.id, ${ }^{4}$ wiga@amikompurwokerto.ac.id \\ *Penulis Korespondensi
}

(Naskah masuk: 19 Maret 2019, diterima untuk diterbitkan: 06 Februari 2020)

\begin{abstract}
Abstrak
Dalam studi ini, kami mengembangkan aplikasi virtual reality untuk mempelajari tata surya di tingkat sekolah dasar. Tujuan pembuatan aplikasi ini untuk menyediakan media pembelajaran berbasis multimedia bagi siswa agar dapat memahami konsep tata surya. Multimedia Development Life Cycle (MDLC) adalah tahap pengembangan sistem yang digunakan untuk membangun aplikasi virtual reality. MDLC terdiri dari tahapan konsep manufaktur, desain, pengumpulan bahan, perakitan, pengujian, dan distribusi. Hasil tes penerimaan pengguna yang dilakukan oleh satu orang guru pengampu menunjukkan hasil $81,25 \%$, sedangkan yang dilakukan oleh 26 siswa menunjukkan hasil 88,63\%. Berdasarkan hasil tes penerimaan oleh guru diperoleh saran perbaikan aplikasi pada sisi interaktifitas pengguna. Evaluasi kepuasan pengguna terhadap aplikasi dilakukan dengan kuesioner berdasarkan empat elemen multimedia: teks, interaktivitas, animasi, dan gambar grafis. Hasil evaluasi penggunaan teks memiliki nilai 3,57, grafik bernilai 3,52, animasi bernilai 3,54, dan interaktivitas memiliki nilai 3,51. Berdasarkan hasil tes, dapat disimpulkan bahwa responden puas dengan penggunaan elemen multimedia pada aplikasi tersebut, dan aplikasi tersebut dapat membantu mereka untuk memahami topik pembelajaran lebih baik daripada metode pembelajaran dan pengajaran konvensional.
\end{abstract}

Kata kunci: virtual reality, tata surya, pengembangan multimedia, evaluasi kepuasan pengguna, elemen multimedia

\section{VIRTUAL REALITY-BASED SOLAR SYSTEM LEARNING MEDIA DEVELOPMENT FOR CLASS 6 STUDENTS ELEMENTARY SCHOOL WITH EVALUATION OF USER SATISFACTION TOWARDS THE MULTIMEDIA ELEMENTS}

\begin{abstract}
In this study, we developed a virtual reality application for learning the solar system at the elementary school. The purpose of making this application is to provide multimedia-based learning media for students to be able to understand the concept of the solar system. Multimedia Development Life Cycle is a development stage of the system used to build virtual reality applications. MDLC consists of stages of the manufacturing concept, design, material collecting, assembly, testing, and distribution. Results of user acceptance test conducted by one teacher show the results of $81.25 \%$, while that is done by 26 student shows the results of $88.63 \%$. Based on the acceptance test results by the teacher, there are suggestions to improve the application on the user interactivity aspect. Evaluation of user satisfaction of the applications is done by a questionnaire based on the four elements of multimedia: text, interactivity, animation, and a graphical image. The result of the evaluation of the use of text has a value of 3.57, the graphic has a value of 3.52, animation has a value of 3.54, and interactivity has a value of 3.51. Based on the test results, it can be concluded that the respondents are satisfied with the use of multimedia elements on the application, and the application can help them to understand the learning topic better than conventional methods of learning dan teaching.
\end{abstract}

Keywords: virtual reality, solar system, multimedia development, evaluation of user satisfaction, multimedia elements 


\section{PENDAhUluan}

Virtual reality (VR) adalah salah satu topik penelitian yang menarik dalam beberapa tahun terakhir untuk dipelajari dan dikembangkan. VR memiliki keunggulan mampu menciptakan lingkungan nyata atau simulasi dimana penerima merasakan visualisasi mendalam dan interaktif (Davelaar dkk., 2018; Seibert dan Shafer, 2018). Penerapan virtual reality telah dilakukan di berbagai bidang, yaitu bidang medis (Rizzo dkk., 2014; Fortmeier $d k k$., 2016; Abushkra dan Faezipour, 2014; Sucar $d k k$., 2014; Vankipuram $d k k$., 2014), penelitian dan pendidikan (Agushinta R. dan Satria, 2018; Barata, Filho \& Nunes, 2015; Ohtani dkk. 2011; Stinson dan Bowman, 2014), pemasaran (Lopez dkk., 2016; Yuan dkk., 2013; Laver $d k k$, 2014), keselamatan (Oliveira $d k k$., 2016), olahraga (Varlet $d k k$., 2018), permainan (Ordaz $d k k$., 2015; Miłaszewicz, 2016; Nugroho dan Chdanrawati, 2018), Sistem Informasi Geografis (Xi-Lin $d k k$, 2014), fashion (Rizaldi, Kurniawati \& Angkoso, 2018) dan robot (Benaoumeur $d k k$., 2015). Tujuan penerapan virtual reality dalam pendidikan untuk mengubah metode pengajaran konvensional yang sebelumnya sulit dipahami karena cara belajar yang kurang interaktif dan menarik agar lebih mudah dipahami oleh siswa dengan penerapan VR. Dalam penelitian ini, kami membangun aplikasi media pembelajaran tata surya di sekolah dasar untuk membantu siswa memahami materi.

Metode pengembangan aplikasi virtual reality umumnya terdiri dari tahapan analisis, desain, pengembangan, dan pengujian aplikasi. Pengujian aplikasi umumnya terdiri dari dua jenis pengujian, yaitu uji alpha dan uji beta. Penelitian yang dilakukan oleh (Vankipuram dkk., 2014; Barata, Filho dan Nunes, 2015; Lopez dkk., 2016; Yuan $d k k$., 2013; Laver $d k k$., 2014; Oliveira $d k k$., 2016; Ordaz dkk., 2015) menggunakan metode pengembangan aplikasi yang umum digunakan. Dalam studi ini, kami memperluas metode pengembangan aplikasi dengan menambahkan evaluasi kepuasan pengguna terhadap elemen multimedia yang digunakan dalam aplikasi. Evaluasi dilakukan setelah langkah-langkah umum diimplementasikan pada pengembangan aplikasi virtual reality. Evaluasi kepuasan pengguna penting untuk dilakukan guna mengetahui tingkat kepuasan dan kesesuaian penggunaan elemen multimedia pada aplikasi. Ketepatan menggunakan elemen multimedia akan membantu siswa mempelajari dan memahami materi.

Dalam penelitian ini, kami mengevaluasi kepuasan pengguna terhadap elemen multimedia berdasarkan empat elemen, yaitu teks, interaktivitas, animasi, dan gambar grafis. Penelitian tentang evaluasi kepuasan pengguna terhadap penggunaan elemen multimedia telah dilakukan sebelumnya oleh (Khedif, Engkamat \& Jack, 2014). Penelitian mereka mengevaluasi kepuasan pengguna tentang penggunaan elemen multimedia dalam suatu mata pelajaran, sedangkan penelitian ini mengevaluasi penggunaan elemen multimedia dalam aplikasi virtual reality.

\section{METODE PENELITIAN}

\subsection{Kerangka Kerja Penelitian}

Fokus penelitian ini untuk mengembangkan aplikasi tata surya berbasis virtual reality dan mengevaluasi kepuasan pengguna terhadap penggunaan elemen multimedia di dalam aplikasi. Dalam penelitian ini, kami menggunakan model Multimedia Development Life Cycle (MDLC) versi (Luther, 1994) untuk mengembangkan aplikasi virtual reality, sementara untuk mengevaluasi kepuasan pengguna terhadap elemen multimedia kami menggunakan model dari penelitian (Khedif, Engkamat dan Jack, 2014). Gambar 1 mengilustrasikan kerangka kerja penelitian kami yang terdiri dari tiga fase.

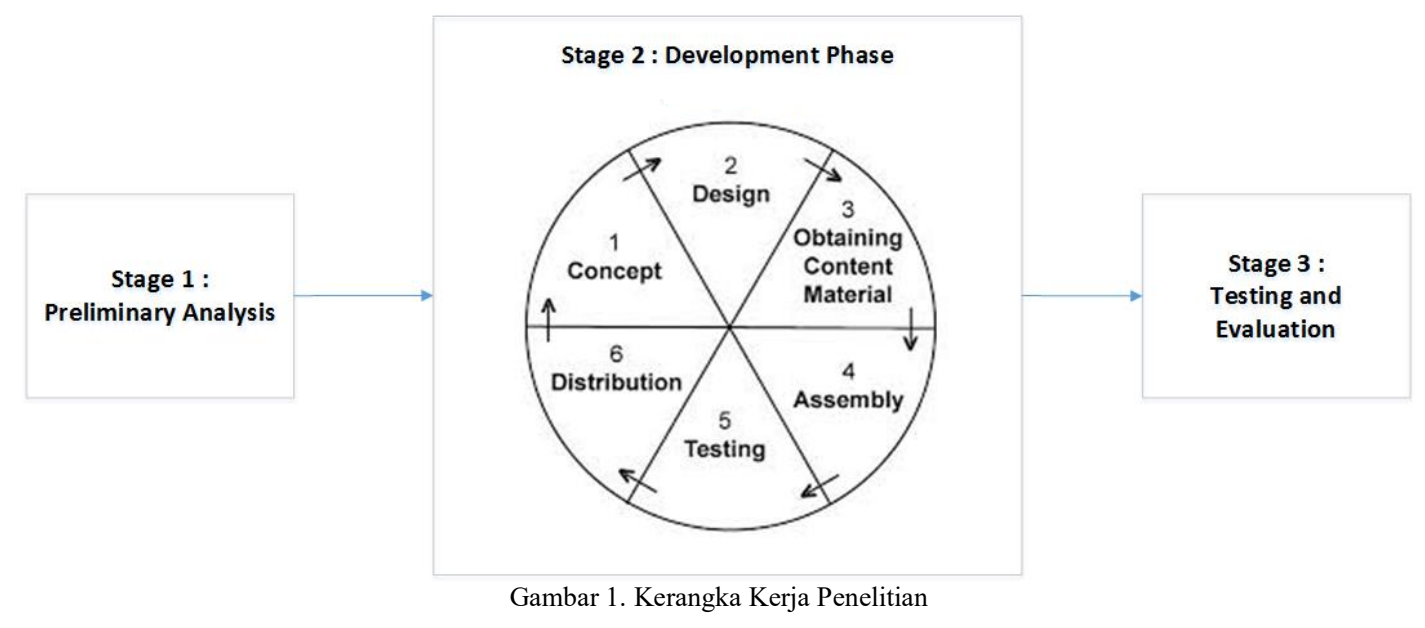




\section{B. Tahap 2: Tahap Pengembangan}

Tahap 2 adalah tahap pengembangan aplikasi virtual reality. Tahap konsep adalah tahap untuk menentukan tujuan aplikasi, aplikasi pengguna akhir, karakteristik pengguna dan spesifikasi aplikasi. Tahap desain adalah tahap pembuatan spesifikasi teknis aplikasi yang meliputi desain antarmuka pengguna, storyboard, desain struktur navigasi pada aplikasi, dan kebutuhan material aplikasi. Fase Pengumpulan Bahan adalah fase pengumpulan bahan yang sesuai dengan kebutuhan aplikasi. Bahan-bahan ini termasuk gambar, video, audio, dan animasi. Tahap perakitan adalah tahap pembuatan aplikasi sesuai dengan desain aplikasi yang telah dibuat. Fase pengujian adalah fase pengujian aplikasi menggunakan uji alpha dan beta. Fase distribusi adalah fase distribusi aplikasi ke pengguna akhir, jika aplikasi memenuhi kebutuhan pengguna.

\section{Tahap 3: Pengujian dan Evaluasi}

Tahap 3 adalah fase evaluasi kepuasan pengguna terhadap elemen multimedia yang digunakan dalam aplikasi. Evaluasi kepuasan pengguna dilakukan dengan kuesioner untuk menilai empat elemen multimedia, yaitu teks, interaktivitas, animasi, dan gambar grafis.

\subsection{Pengumpulan Data}

Tes penerimaan pengguna (uji beta) dilakukan dengan pengisian kuesioner oleh 26 siswa dan satu guru, setelah mereka selesai menguji aplikasi. Tabel 1 dan 2 menggambarkan kuesioner yang digunakan untuk uji beta tersebut.

Tabel 1. Kuesioner Tes Beta untuk Guru

\begin{tabular}{|c|c|c|c|c|c|}
\hline \multirow[b]{2}{*}{ No. } & \multirow[b]{2}{*}{ Aspek } & \multicolumn{4}{|c|}{ Rating } \\
\hline & & Sangat Setuju & Setuju & $\begin{array}{r}\text { Tidak } \\
\text { Setuju }\end{array}$ & $\begin{array}{c}\text { Sangat Tidak } \\
\text { Setuju }\end{array}$ \\
\hline $\begin{array}{l}1 . \\
2 . \\
3 . \\
4 .\end{array}$ & $\begin{array}{l}\text { Tampilan aplikasi tata surya sangat } \\
\text { menarik dan interaktif } \\
\text { Teks pada aplikasi jelas dan mudah } \\
\text { dimengerti } \\
\text { Aplikasi sudah tepat untuk digunakan } \\
\text { Bahan-bahan pada aplikasi tata surya sesuai } \\
\text { dengan buku pedoman }\end{array}$ & & & & \\
\hline \multicolumn{6}{|c|}{ Tabel 2. Kuesioner Tes Beta untuk Siswa } \\
\hline \multirow[b]{2}{*}{ No. } & \multirow[b]{2}{*}{ Aspek } & \multicolumn{4}{|c|}{ Rating } \\
\hline & & Sangat Setuju & Setuju & $\begin{array}{c}\text { Tidak } \\
\text { Setuju }\end{array}$ & $\begin{array}{l}\text { Sangat Tidak } \\
\text { Setuju }\end{array}$ \\
\hline 1. & Tampilan aplikasi tata surya cukup menarik & & & & \\
\hline 2. & $\begin{array}{l}\text { Saya senang mempelajari materi tata surya } \\
\text { menggunakan aplikasi ini }\end{array}$ & & & & \\
\hline 3. & Aplikasi mudah digunakan & & & & \\
\hline 4. & $\begin{array}{l}\text { Saya terhibur karena aplikasi ini memiliki } \\
\text { animasi }\end{array}$ & & & & \\
\hline
\end{tabular}

Rating Sangat Setuju bernilai 4, Setuju bernilai 3, Tidak Setuju bernilai 2, dan Sangat Tidak Setuju bernilai 1. Selanjutnya, data kuesioner diproses menggunakan skala pengukuran Likert (1932).

Setelah Tahap 2: Tahap pengembangan selesai, berikutnya dilakukan evaluasi kepuasan pengguna terhadap penggunaan elemen multimedia pada aplikasi. Pengujian dilakukan dengan kuesioner yang diisi oleh 30 siswa sebagai responden. Daftar aspek evaluasi dari setiap elemen diambil dari penelitian yang dilakukan oleh (Khedif, Engkamat \& Jack, 2014). Selanjutnya, data kuesioner diproses menggunakan perangkat lunak IBM SPSS Statistics untuk menghitung nilai rata-rata dan standar deviasi.

\section{HASIL DAN PEMBAHASAN}

Aplikasi tata surya berbasis virtual reality dibangun menggunakan perangkat lunak Unity $3 D$ Engine. Perangkat lunak ini telah digunakan oleh para peneliti sebelumnya di beberapa bidang seperti robotika (Bartneck dkk., 2015), aplikasi virtual reality (Rizzo $d k k$., 2014), permainan mobile berbasis augmented reality (Kim dkk., 2014), serta simulasi dan pemodelan (Ferworn dkk., 2013). Berdasarkan kemampuan Unity Engine yang dapat digunakan untuk mengembangkan aplikasi virtual reality, maka kami memutuskan untuk menggunakan perangkat lunak ini sebagai alat dalam pengembangan lingkungan virtual reality kami. Objek tata surya dalam aplikasi ini adalah planet, benda langit lainnya (asteroid, komet, meteorit, dan satelit), dan matahari. Objek tata surya yang digunakan dalam aplikasi ini disesuaikan dengan materi ilmu pengetahuan alam di tingkat sekolah dasar. Aplikasi virtual reality memiliki ekstensi file .apk yang ditujukan untuk platform Android.

Penelitian terdahulu mengenai pengembangan media pembelajaran tata surya berbasis virtual reality yang dilakukan oleh Muttaqin $d k k$. (2016) dan Prayudha dkk. (2017) berfokus pada pengenalan dan pemahaman mengenai planet, sedangkan studi yang dilakukan oleh Abdussalam dkk. (2018) berfokus pada kajian tentang planet dan matahari. Produk penelitian kami tidak hanya memberikan materi tentang planet dan matahari kepada siswa 
tetapi juga menyediakan kajian sistem tata surya bima sakti dan pengenalan benda luar angkasa lainnya seperti asteroid, komet, meteoroid, satelit, dan pluto.

\subsection{Aplikasi Tata Surya Berbasis Virtual Reality}

Implementasi aplikasi tata surya didasarkan pada desain aplikasi yang telah dibuat dalam bentuk desain antarmuka pengguna, storyboard dan desain struktur menu pada aplikasi. Gambar 2 menunjukkan struktur menu dalam aplikasi virtual reality. Terdapat 4 objek benda luar angkasa dalam di aplikasi, yaitu delapan planet di dalam sistem tata surya, benda luar angkasa selain planet, matahari, dan sistem tata surya.

Pada fase uji beta di dalam MDLC, dua puluh enam siswa dan satu guru menguji kelayakan aplikasi dan mengisi kuesioner seperti pada Tabel 1 dan Tabel 2. Kami menguji aplikasi menggunakan smartphone Asus Zenfone ZE550KL dan Google CardBoard. Smartphone ini memiliki spesifikasi Prosesor: Qualcomm MSM8916 Snapdragon 410 Quad-core 1.2 GHz Cortex-A53, RAM: 2GB, Android OS v5.0 (Lollipop), dan GPU: Adreno 306. Berdasarkan uji beta yang dilakukan oleh guru, diperoleh nilai kelayakan sebesar 81,25\%, sedangkan hasil tes yang dilakukan oleh siswa, memiliki nilai kelayakan sebesar 88,63\%. Berdasarkan hasil tes ini, dapat disimpulkan bahwa aplikasi tersebut telah memenuhi syarat untuk digunakan dalam proses pembelajaran tata surya. Pada tes tersebut, pihak guru memberikan saran perbaikan terhadap aplikasi di sisi interaktifitas pengguna.

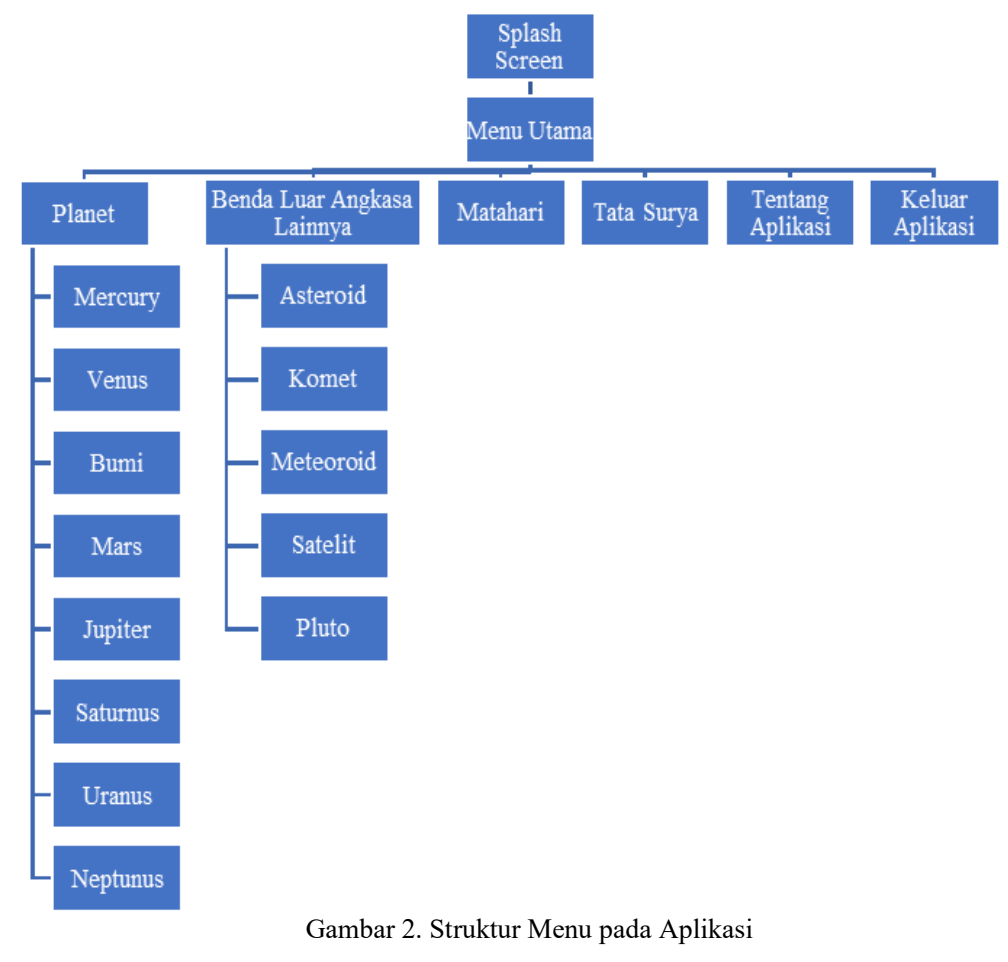

Gambar 3 menjelaskan tampilan hasil akhir aplikasi pada fase Assembly dalam tahapan MDLC. Gambar 3 (a) menunjukkan gambar splash screen, tampilan tersebut akan tampil pertama kali saat pertama kali aplikasi dijalankan, layar splash akan otomatis hilang dan selanjutnya pengguna aplikasi diarahkan ke Menu Utama seperti yang ditunjukkan pada Gambar 3 (b), pada menu utama pengguna aplikasi dapat memilih pokok bahasan yang akan dipelajari, seperti Tata Surya, Matahari, Benda Luar Angkasa dan Planet.

Apabila pengguna aplikasi memilih pokok bahasan Tata Surya, maka tampilan VR dapat dilihat pada Gambar 3 (c), VR tersbut dapat menggambarkan komponen-komponen apa saja yang terdapat pada Tata Surya, dan juga bagaimana sistem Tata Surya bekerja. Apabila pengguna memilih menu Benda Luar Angkasa dan memilih sub-menu Komet, maka tampilan yang akan muncul dapat dilihat pada Gambar 3 (d), selain menggambarkan bentuk Komet, aplikasi juga menjelaskan pengertian Komet dan bagaimana cara kerja Komet. 


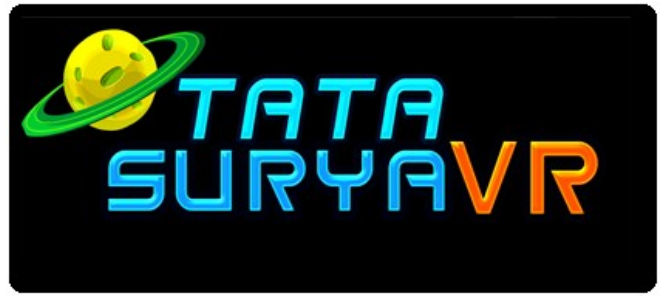

(a)

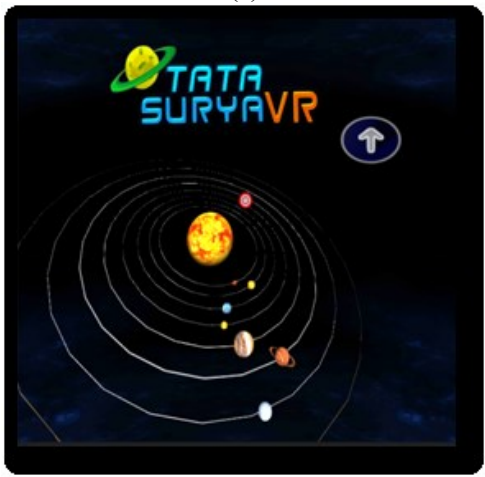

(c)

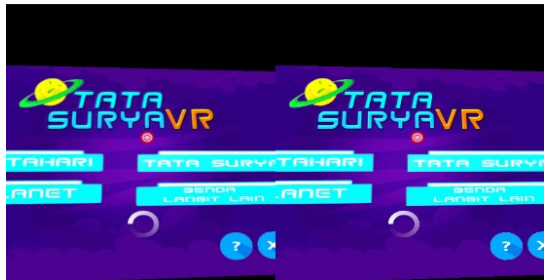

(b)

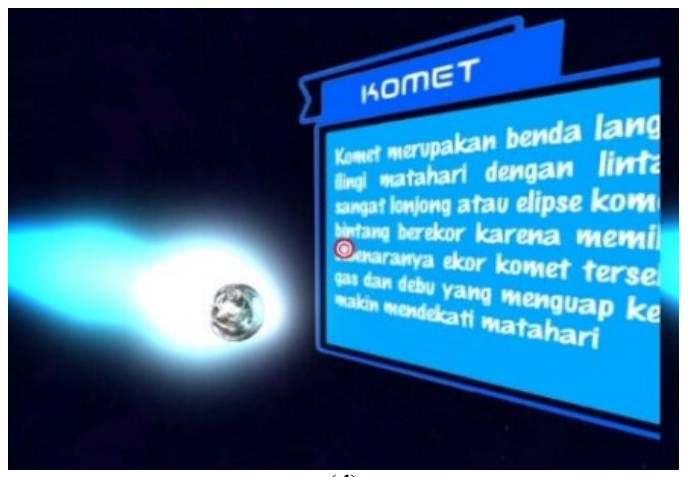

(d)

Gambar 3. Layar Splash (a), Menu Utama (b), Sistem Tata Surya (c), dan Penjelasan Komet (d)

\subsection{Hasil Pengujian dan Evaluasi Kepuasan Pengguna terhadap Elemen Multimedia}

Pengujian dan evaluasi kepuasan pengguna terhadap penggunaan elemen multimedia dalam aplikasi tata surya dilakukan oleh 30 siswa sebagai responden. Tabel 3 hingga Tabel 6 menunjukkan hasil pemrosesan data kuesioner menggunakan perangkat lunak IBM SPSS Statistics untuk menghitung nilai rata-rata dan standar deviasi setiap elemen multimedia.

\begin{tabular}{clcc}
\multicolumn{3}{c}{ Tabel 3. Nilai Rata-Rata dan Standar Deviasi untuk Elemen Teks } \\
\hline No. & \multicolumn{1}{c}{ Aspek } & $\begin{array}{c}\text { Rata- } \\
\text { rata }\end{array}$ & $\begin{array}{c}\text { Standar } \\
\text { Deviasi }\end{array}$ \\
\hline 1. & Teks mudah dibaca & 3.73 & .450 \\
2. & Kualitas huruf baik & 3.63 & .490 \\
3. & Tampilan teks jelas & 3.47 & .507 \\
4. & $\begin{array}{l}\text { Posisi informasi tampak } \\
\text { jelas }\end{array}$ & 3.57 & .504 \\
5. & $\begin{array}{l}\text { Teks narasi mudah } \\
\text { dimengerti }\end{array}$ & 3.47 & .507 \\
\hline
\end{tabular}

Berdasarkan hasil pengujian terhadap elemen teks pada Tabel 3, dapat disimpulkan bahwa siswa hampir setuju dengan penulisan teks (Pertanyaan 1), jenis huruf (Pertanyaan 2), tata letak teks (Pertanyaan 3), posisi teks aplikasi (Pertanyaan 4), dan mampu memahami teks berisi narasi penjelasan yang diberikan aplikasi (Pertanyaan 5). Ini dibuktikan dengan nilai rata-rata (Mean) $>3,00$ dari nilai maksimum 4 untuk semua aspek penilaian.

Berdasarkan hasil pengujian terhadap elemen Gambar Grafis pada Tabel 4, dapat disimpulkan bahwa siswa hampir setuju dengan penggunaan warna (Pertanyaan 1) dan grafik (Pertanyaan 3). Selain itu, grafik mudah dipahami (Pertanyaan 2) dan anotasi penggunaan media grafis yang mudah dipahami (Pertanyaan 4) oleh siswa.
Tabel 4. Nilai Rata-Rata dan Standar Deviasi untuk Elemen

\begin{tabular}{|c|c|c|c|}
\hline \multicolumn{4}{|c|}{ Gambar } \\
\hline No. & Aspek & $\begin{array}{l}\text { Rata- } \\
\text { rata }\end{array}$ & $\begin{array}{l}\text { Standar } \\
\text { Deviasi }\end{array}$ \\
\hline 1. & $\begin{array}{l}\text { Warna yang digunakan } \\
\text { menarik }\end{array}$ & 3.47 & .507 \\
\hline 2. & Grafik jelas & 3.50 & .509 \\
\hline 3. & $\begin{array}{l}\text { Grafik yang digunakan } \\
\text { sesuai }\end{array}$ & 3.70 & .466 \\
\hline 4. & $\begin{array}{l}\text { Penjelasan menggunakan } \\
\text { grafik mudah dimengerti }\end{array}$ & 3.40 & .498 \\
\hline
\end{tabular}

Tabel 5. Nilai Rata-Rata dan Standar Deviasi untuk Elemen

\begin{tabular}{|c|c|c|c|}
\hline \multicolumn{4}{|c|}{ Animasi } \\
\hline No. & Aspek & $\begin{array}{l}\text { Rata- } \\
\text { rata }\end{array}$ & $\begin{array}{l}\text { Standar } \\
\text { Deviasi }\end{array}$ \\
\hline 1. & $\begin{array}{l}\text { Animasi yang digunakan dalam } \\
\text { penjelasan sangat membantu } \\
\text { untuk memahami topik }\end{array}$ & 3.50 & .509 \\
\hline 2. & $\begin{array}{lrr}\text { Elemen } & \text { animasi } & \text { yang } \\
\text { digunakan } & \text { cocok } & \text { untuk } \\
\text { menjelaskan topik } & \end{array}$ & 3.67 & .479 \\
\hline 3. & Animasi menarik & 3.43 & .504 \\
\hline 4. & $\begin{array}{l}\text { Animasi dapat membantu } \\
\text { memvisualisasikan topik }\end{array}$ & 3.57 & .504 \\
\hline
\end{tabular}

Berdasarkan hasil pengujian elemen animasi pada Tabel 5, dapat disimpulkan bahwa siswa hampir setuju dengan penggunaan animasi untuk memahami topik tata surya (Pertanyaan 1), animasi yang digunakan sesuai dengan topik (Pertanyaan 2), animasi yang digunakan menarik (Pertanyaan 3), dan animasi mampu memvisualisasikan topik mengenai tata surya (Pertanyaan 4).

Berdasarkan hasil pengujian terhadap elemen Interaktivitas pada Tabel 6, dapat disimpulkan bahwa siswa hampir setuju dengan cara pengguna berinteraksi dengan aplikasi (Pertanyaan 1), pengguna dapat menavigasikan aplikasi dengan 
mudah (Pertanyaan 2), menggunakan tautan (Pertanyaan 3) dan tombol sesuai dengan standar (Pertanyaan 4).

Tabel 6. Nilai Rata-rata dan Standar Deviasi untuk Elemen Interaktivitas

\begin{tabular}{|c|c|c|c|c|}
\hline No. & Aspek & & $\begin{array}{c}\text { Rata- } \\
\text { rata }\end{array}$ & $\begin{array}{l}\text { Standar } \\
\text { Deviasi }\end{array}$ \\
\hline 1. & $\begin{array}{l}\text { Alat interaktivitas } \\
\text { digunakan }\end{array}$ & mudah & 3.47 & .507 \\
\hline 2. & Navigasi mudah & & 3.57 & .504 \\
\hline 3. & Tautan yang digunak & enar & 3.47 & .507 \\
\hline 4. & $\begin{array}{ll}\text { Tombol } & \text { standar } \\
\text { digunakan } & \end{array}$ & yang & 3.53 & .507 \\
\hline
\end{tabular}

Hasil evaluasi kepuasan pengguna untuk setiap elemen multimedia menunjukkan bahwa elemen teks memiliki nilai rata-rata tertinggi, sedangkan elemen interaktivitas memiliki nilai rata-rata terendah dibandingkan dengan nilai rata-rata elemen multimedia lainnya. Gambar 4 menunjukkan grafik dari nilai rata-rata setiap elemen multimedia dalam aplikasi tata surya.

Berdasarkan Gambar 4, karena nilai rata-rata elemen interaktivitas memiliki nilai terendah, jika dibandingkan dengan nilai elemen multimedia lainnya, maka perlu ada peningkatan elemen interaktivitas yang digunakan di dalam aplikasi.

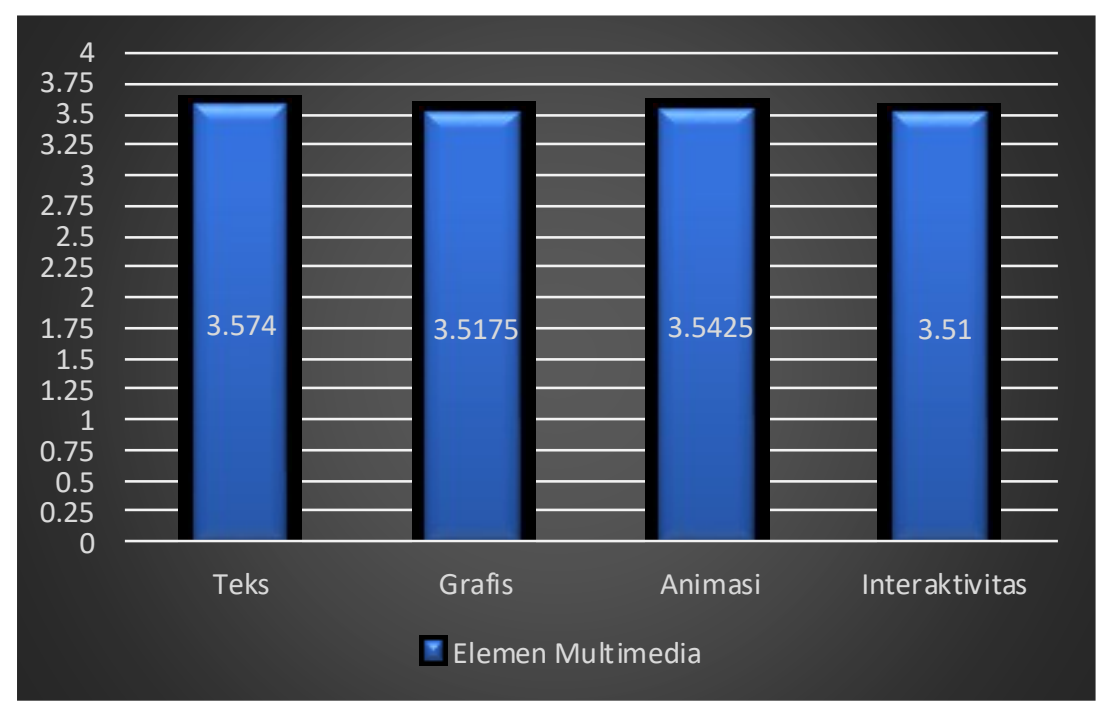

Gambar 4. Perbandingan Nilai Rata-Rata Keseluruhan Elemen Multimedia

\section{KESIMPULAN}

Hasil uji beta yang dilakukan oleh guru menunjukkan nilai kelayakan $81,25 \%$, sedangkan tes yang dilakukan oleh siswa menunjukkan nilai kelayakan 88,63\%. Dari hasil uji Beta, dapat disimpulkan bahwa aplikasi tersebut telah memenuhi syarat untuk digunakan dalam proses pembelajaran tata surya. Selain itu, hasil evaluasi kepuasan pengguna dari empat elemen multimedia menunjukkan bahwa penggunaan teks dalam aplikasi memiliki nilai rata-rata 3,57 ; grafik memiliki nilai rata-rata 3,52 ; animasi memiliki nilai rata-rata 3,54 ; dan interaktivitas memiliki nilai ratarata 3,51. Berdasarkan hasil pengujian, dapat disimpulkan bahwa responden puas dengan penggunaan elemen multimedia pada aplikasi.

\section{UCAPAN TERIMA KASIH}

Penulis mengucapkan terima kasih atas dukungan pendanaan penelitian dari STMIK AMIKOM Purwokerto dan mengucapkan terima kasih kepada kepala sekolah, guru, staf, dan siswa Sekolah Dasar Negeri 08 Sidanegara Cilacap, Jawa
Tengah yang telah mendukung pelaksanaan penelitian ini.

\section{DAFTAR PUSTAKA}

ABDUSSALAM, A., SULTHONI, S. dan MUNZIL, M. (2018) 'Media Virtual Reality Tata Surya untuk Meningkatkan Kemampuan Retensi', Jurnal Pendidikan: Teori, Penelitian, dan Pengembangan, 3(9), pp. 1160-1167. doi:10.17977/jptpp.v3i9.11527.

ABUSHKRA, A. dan FAEZIPOUR, M. (2014) 'Augmenting Breath Regulation Using a Mobile Driven Virtual Reality Therapy Framework', IEEE Journal of Biomedical and Health Informatics, 18(3), pp. 746752. doi: 10.1109/JBHI.2013.2281195.

AGUSHINTA R., D. dan SATRIA, A. (2018) 'Pembelajaran 3D Sistem Ekskresi Manusia Berbasis Virtual Reality dan Android', Jurnal Teknologi Informasi dan Ilmu Komputer, 5(4), p. 381. doi: 10.25126/jtiik.201854665.

BARATA, P. N. A., FILHO, M. R. dan NUNES, M. V. A. (2015) 'Consolidating Learning in Power Systems: Virtual Reality Applied to 
the Study of the Operation of Electric Power Transformers', Ieee Transactions on Education, 58(4), pp. 255-261. doi: 10.1109/TE.2015.2393842.

BARTNECK, C. $d k k$. (2015) 'The robot engine Making the unity 3D game engine work for HRI', in Symposium on Robot and Human Interactive Communication. Kobe: IEEE, pp. 431-437. doi: 10.1109/ROMAN.2015.7333561.

BENAOUMEUR, I. $d k k$. (2015) 'Remote Control of Mobile Robot using the Virtual Reality', International Journal of Electrical and Computer Engineering (IJECE), 5(5), pp. 1062-1074. doi: 10.11591/ijece.v5i5.7692.

DAVELAAR, J., BRONZWAER, T., KOK, D., YOUNSI, Z., MOŚCIBRODZKA, M. dan FALCKE, H. (2018) 'Observing supermassive black holes in virtual reality', Computational Astrophysics and Cosmology, 5(1), pp. 1-17. doi: 10.1186/s40668-018-0023-7.

FERWORN, A. $d k k$. (2013) 'Disaster Scene Reconstruction: Modeling and Simulating Urban Building Collapse Rubble Within a Game Engine', in Proceedings of the 2013 Summer Computer Simulation Conference. Vista, CA: Society for Modeling; Simulation International (SCSC '13), p. 18:1--18:6. Available at http://dl.acm.org/citation.cfm?id=2557696. 2557717.

FORTMEIER, D. $d k k$. (2016) 'A virtual reality system for PTCD simulation using direct visuo-haptic rendering of partially segmented image data', IEEE Journal of Biomedical and Health Informatics, 20(1), pp. 355-366. doi: 10.1109/JBHI.2014.2381772.

KHEDIF, L. Y. B., ENGKAMAT, A. \& JACK, S. (2014) 'The Evaluation of Users' Satisfaction towards the Multimedia Elements in a Courseware', Procedia Social and Behavioral Sciences. Elsevier B.V., 123, pp. 249-255. doi: 10.1016/j.sbspro.2014.01.1421.

KIM, S. L. $d k k$. (2014) 'Using Unity 3D to facilitate mobile augmented reality game development', in 2014 IEEE World Forum on Internet of Things, WF-IoT 2014, pp. 21-26. doi: 10.1109/WFIoT.2014.6803110.

LAVER, K. $d k k$. (2014) 'Virtual Reality Grocery Shopping Simulator: Development and Usability in Neurological Rehabilitation', Presence: Teleoperators and Virtual Environments, 21(2), pp. 183-191. doi: 10.1162/pres_a_00098.
LIKERT, R. (1932) 'A Technique For The Measurement of Attitude, Archieves of Psychology: New York University', Archives of Psychology, 22(140), pp. 5-55. doi: 2731047.

LOPEZ, M. M. $d k k$. (2016) "An "In the Wild" Experiment on Presence and Embodiment using Consumer Virtual Reality Equipment', IEEE Transactions on Visualization and Computer Graphics, 22(4), pp. 1406-1414. doi: 10.1109/tvcg.2016.2518135.

LUTHER, A. C. (1994) Authoring Interactive Multimedia. Boston: Boston: AP Professional. Available at: https://archive.org/details/authoringinterac0 0luth.

MIŁASZEWICZ, D. (2016) 'Games Using Virtual Reality as a Tool in Economics Experiments', in Springer Proceedings in Business and Economics. Szczecin: Springer International Publishing Switzerland, pp. 15-27. doi: 10.1007/9783-319-28419-4.

MUTTAQIN, D., ARIFIN, F. dan FARIDA, L. N. (2016) 'Planetarium: Aplikasi Pembelajaran Sistem Tata Surya Berbasis Virtual Reality', e-Proceeding of Applied Science, 2(2), pp. 713-721.

NUGROHO, E. W. dan CHANDRAWATI, T. B. (2018) 'Detection H and Motion on Virtual Reality Mathematics Game with Accelerometer and Flex Sensors', TELKOMNIKA, 16(5), pp. 2287-2292. doi: 10.12928/TELKOMNIKA.v16i5.7594.

OHTANI, H. $d k k$. (2011) 'Scientific visualization of plasma simulation results and device data in virtual-reality space', IEEE Transactions on Plasma Science, 39(11 PART 1), pp. 2472-2473.

doi: 10.1109/TPS.2011.2157174.

OLIVEIRA, J. $d k k$. (2016) 'Using Immersive Virtual Reality to Reduce Work Accidents in Developing Countries', IEEE Computer Graphics and Applications, 36(2), pp. 3646. doi: 10.1109/mcg.2016.19.

ORDAZ, N. $d k k$. (2015) 'Serious Games and Virtual Simulator for Automotive Manufacturing Education \& Training', Procedia Computer Science. Elsevier Masson SAS, 75, pp. 267-274. doi: 10.1016/j.procs.2015.12.247.

PRAYUDHA, I. P. A., WIRANATHA, A. A. K. A. C. dan RAHARJA, I. M. S. (2017) 'Aplikasi Virtual Reality Media Pembelajaran Sistem Tata Surya', Jurnal Ilmiah Merpati (Menara Penelitian Akademika Teknologi Informasi), 5(2), pp. 72-80. 
RIZALDI, R., KURNIAWATI, A. dan ANGKOSO, C. V. (2018) 'Implementasi Metode Euclidean Distance untuk Rekomendasi Ukuran Pakaian pada Aplikasi Ruang Ganti Virtual', Jurnal Teknologi Informasi dan Ilmu Komputer, 5(2), p. 129. doi: 10.25126/jtiik.201852592.

RIZZO, A. $d k k$. (2014) 'Virtual Reality Exposure Posttraumatic Combat-Related Therapy for Stress Disorder', Computer, 47(7), pp. 3137.

SEIBERT, J. dan SHAFER, D. M. (2018) 'Control mapping in virtual reality: effects on spatial presence and controller naturalness', Virtual Reality, 22(1), pp. 79-88. doi: 10.1007/s10055-017-0316-1.

STINSON, C. dan BOWMAN, D. A. (2014) 'Feasibility of training athletes for highpressure situations using virtual reality', IEEE Transactions on Visualization and Computer Graphics, 20(4), pp. 606-615. doi: 10.1109/TVCG.2014.23.

SUCAR, L. E. $d k k$. (2014) 'Gesture Therapy: An Upper Limb Virtual Reality-Based Motor Rehabilitation Platform', IEEE Transactions on Neural Systems and Rehabilitation Engineering, 22(3), pp. 634643. doi: 10.1109/tnsre.2013.2293673.

VANKIPURAM, A. $d k k$. (2014) 'Design and development of a virtual reality simulator for advanced cardiac life support training', IEEE Journal of Biomedical and Health Informatics, 18(4), pp. 1478-1484. doi: 10.1109/JBHI.2013.2285102.

VARLET, M. $d k k$. (2018) 'Virtual Reality as a Tool to Learn Interpersonal Coordination: Example of Team Rowing', Presence, 22(3), pp. 202-215. doi: 10.1162/PRES.

XI-LIN, K. $d k k$. (2014) 'Construction and Application of Virtual Reality Geographic Information System', TELKOMNIKA Indonesian Journal of Electrical Engineering, 12(6), pp. 4353-4360. doi: 10.11591/telkomnika.v12i6.4872.

YUAN, M. $d k k$. (2013) 'A mixed reality virtual clothes try-on system', IEEE Transactions on Multimedia, 15(8), pp. 1958-1968. doi: 10.1109/TMM.2013.2280560. 